Review

\title{
How Active Are Porcine Endogenous Retroviruses (PERVs)?
}

\author{
Joachim Denner \\ Robert Koch Institute, Nordufer 20, 13353 Berlin, Germany; DennerJ@rki.de; Tel.: +49-30-187542800 \\ Academic Editor: Alexander Ploss \\ Received: 16 March 2016; Accepted: 22 July 2016; Published: 3 August 2016
}

\begin{abstract}
Porcine endogenous retroviruses (PERVs) represent a risk factor if porcine cells, tissues, or organs were to be transplanted into human recipients to alleviate the shortage of human transplants; a procedure called xenotransplantation. In contrast to human endogenous retroviruses (HERVs), which are mostly defective and not replication-competent, PERVs are released from normal pig cells and are infectious. PERV-A and PERV-B are polytropic viruses infecting cells of several species, among them humans; whereas PERV-C is an ecotropic virus infecting only pig cells. Virus infection was shown in co-culture experiments, but also in vivo, in the pig, leading to de novo integration of proviruses in certain organs. This was shown by measurement of the copy number per cell, finding different numbers in different organs. In addition, recombinations between PERV-A and PERV-C were observed and the recombinant PERV-A/C were found to be integrated in cells of different organs, but not in the germ line of the animals. Here, the evidence for such in vivo activities of PERVs, including expression as mRNA, protein and virus particles, de novo infection and recombination, will be summarised. These activities make screening of pigs for provirus number and PERV expression level difficult, especially when only blood or ear biopsies are available for analysis. Highly sensitive methods to measure the copy number and the expression level will be required when selecting pigs with low copy number and low expression of PERV as well as when inactivating PERVs using the clustered regularly interspaced short palindromic repeats (CRISPR)/CRISPR-associated nuclease (CRISPR/Cas) technology.
\end{abstract}

Keywords: porcine endogenous retroviruses; human endogenous retroviruses; xenotransplantation; retroviruses

\section{Introduction}

Endogenous retroviruses are the result of an infection of germ cells with a retrovirus leading to the integration of the viral genome as DNA copy (provirus) in all cells of the organism [1-3]. Human endogenous retroviruses (HERVs), especially HERV-K, are well characterised and it has been shown that most of them are defective: if they are expressed in human tumour cells, they are rarely released as particles and even if they are not defective then they are not infectious [4]. Since the integration of HERVs took place millions of years ago and HERVs are inactive, the copy number per cell is identical in all cells of a human individual. Concerning (i) the integration site; (ii) the presence of all proviruses and (iii) mutations in the viral sequences, minor differences exist between the individuals. Although HERVs are replication inactive, it is important to note that proteins encoded by HERVs and endogenous retroviruses of other mammalians are utilised for physiological functions of the host. The Env proteins are required for the generation of a functional placenta using the fusion competence of this protein (for review see [5]). Interestingly, in different species different proviruses were utilised for this function. In addition, Env proteins may be involved in immunosuppression required for the survival of the embryo [6] and recent data suggest that endogenous retroviruses are involved in the regulation of the innate immunity [7]. In contrast to HERVs, endogenous retroviruses of many other 
species, especially endogenous gammaretroviruses, are released as virus particles and can infect cells of their own species and/or of other species [8].

The porcine endogenous retroviruses (PERVs) are not very well studied. PERVs are gammaretroviruses closely related to murine leukaemia viruses (MuLV), feline leukaemia viruses (FeLV) and koala retroviruses (KoRV). PERVs are of interest in the context of xenotransplantation, which is under development in order to alleviate the shortage of human tissues and organs for the treatment of tissue and organ failure. Pigs are for several reasons (e.g., size, physiological similarity with humans, availability, multiparity, availability of multiple genetic changes to prevent immunological rejection) the preferred donor animals. PERVs are released from normal pig cells and are infectious. PERV-A and PERV-B are polytropic viruses infecting cells from several species among them humans, and therefore they pose a risk for xenotransplantation. PERV-C is an ecotropic virus infecting only pig cells. Virus infectivity was shown in co-culture experiments in vitro (for review see $[9,10])$. In recent years, evidence accumulated that PERVs are-in contrast to HERVs—still active in vivo, in the pig. In contrast to HERVs which are expressed as mRNA, protein and non-infectious particles, PERVs are still more active in vivo, in the pig. Here, data demonstrating the activity of PERVs, e.g., the expression of the proviruses, their replication, de novo integration in vivo, and recombination in pigs will be analysed, and the implication for testing pigs for xenotransplantation will be discussed.

\section{Evidence for Replication and de Novo Integration in Vivo}

In the case of HERVs, the copy number per cell is identical in all cells of one individual and is more or less identical in all individuals of the species. This is true for example for HERV-K which was introduced into the human germ line 28 millions years ago [11]. Findings that PERV-A and PERV-B are present in Suiformes, and PERV-C was detectable only in Sus scrofa and in closely related species, suggested an African origin of PERV of about 7.5 million years ago. It seems likely that PERV-C originated more recently ( 1.5 to 3.5 million years ago) by recombination with unknown homologous sequences [12,13].

The copy numbers of PERV in different breeds, in different animals of one breed, in different organs of one and the same animal and in pig cell lines are poorly studied (Table 1) [14-26]. In Chinese miniature pigs the copy number in the genomic DNA was reported to vary significantly, ranging from four to 96 copies [17]. Some animals had a low number of proviruses, a low expression at the RNA level and were PERV-C free. The absence of PERV-C prevents the formation of recombinant PERV-A/C variants which can replicate at a higher rate when compared with the maternal PERV-A and which can infect in contrast to PERV-C human cells (for review see [27]). Therefore, these animals are good candidates for use in xenotransplantation. When five different pig breeds including the Iberian pig were studied in Spain, copy numbers between three and 43 were found and no correlation between the copy number and the heterozygosity or inbreeding coefficient was detected [21]. In another study, approximately 40 copies have been reported in miniature pigs, 30 in Duroc pigs, 20 in Landrace pigs, 25 in Yorkshire pigs and 15 in Korean Jeju pigs analysing DNA from peripheral blood mononuclear cells (PBMCs) [18]. 
Table 1. Reported porcine endogenous retrovirus (PERV) copy numbers in different pig breeds and cell lines.

\begin{tabular}{|c|c|c|c|}
\hline Pig Breed, Pig Cell Line & Copy Number & Method & Reference \\
\hline Landrace $\times$ Duroc, Meishan, Pietrain & $\begin{array}{c}\text { 10-23 (PERV-A), } \\
\text { 7-12 (PERV-B) } \\
50 \text { (protease) }\end{array}$ & Southern blot & $\begin{array}{l}\text { Le Tissier et al., [14]; } \\
\text { Patience et al., [15] }\end{array}$ \\
\hline Landrace $\times$ Duroc & $32-64$ & PCR titration & Patience et al. [16] \\
\hline Chinese miniature pigs ${ }^{a}$ & $3.95 \pm 0.14$ to $95.52 \pm 2.20$ & Real-time PCR & Liu et al., [17] \\
\hline Six breeds in Korea, Duroc, Landrace, Yorkshire & 9 to 50 & & Lee et al., [18] \\
\hline Seven organs of four Landrace $\times$ Jeju pigs & $28.0 \pm 2.7$ & Real-time PCR & Yoon et al., [19] \\
\hline Chinese Banna minipig inbreed ${ }^{b}$ & 1.4 to $98.1(\mathrm{pol})^{\mathrm{b}}$ & Real-time PCR & Zhand et al., [20] \\
\hline Spanish wild boars and commercial pigs & 3 to $43(\mathrm{pol})^{\mathrm{c}}$ & Real-time PCR & Quereda et al., [21] \\
\hline $\begin{array}{c}\text { Pietran } \\
\text { Hampshire } \\
\text { Meishan } \\
\text { Wild boar } \\
\text { Large white } \\
\text { Dutch landrace }\end{array}$ & $\begin{array}{c}11.7^{\mathrm{d}} / 1.6^{\mathrm{e}} \\
14.0 / 2.2 \\
12.1 / 2.8 \\
3.7 / 0 \\
10.2 / 0 \\
6.7 / 2.8 \\
\end{array}$ & Real-time PCR & Mang et al., [22] \\
\hline Westran pigs & $\begin{array}{l}19 \text { PERV-A } \\
13 \text { PERV-B }\end{array}$ & Fluorescence in situ hybridization (FISH) & Lee et al., [23] \\
\hline Auckland Island pigs & 3 to 37 & $\begin{array}{c}\text { Real-time PCR, PCR-based limited } \\
\text { dilution assay }\end{array}$ & Garkavenko et al., [24] \\
\hline Duroc pig & $\begin{array}{c}20 \text { Gamma }^{\mathrm{f}} \\
4 \text { Beta }^{\mathrm{g}}\end{array}$ & Genome wide sequencing & Groenen et al., [25] \\
\hline PK15 cells & 62 & Droplet digital PCR & Yang et al., [26] \\
\hline
\end{tabular}

a Expression $3.66 \pm 0.13$ to $43.93 \pm 2.5$ (real-time RT-PCR); ${ }^{\text {b }}$ Highest copy number detected with primers detecting the polymerase gene (pol), highest number in spleen, hearts, ileum

${ }^{\mathrm{c}}$ Primers detecting the polymerase gene ( $\left.p o l\right)$ of PERV-A, $-\mathrm{B}$ and $-\mathrm{C}$; ${ }^{\mathrm{d}}$ PERV-A and PERV-B using PERV-A/B specific env primers; ${ }^{\text {e }}$ PERV-C using PERV-C specific env primers; ${ }^{\mathrm{f}}$ Gammaretroviruses; ${ }^{\mathrm{g}}$ Betaretroviruses. 
Whereas some studies showed identical numbers of proviruses in different organs of a single pig [19], others have demonstrated differences in the copy number of PERV between different organs of one pig $[20,28,29]$. This finding was unexpected. On one hand, technical factors such as the way how the DNA has been isolated from different organs, the purity of the DNA, the sensitivity of the PCR, and tissue-specific contaminations affecting the PCR method may contribute to different copy numbers in a single individual. In addition, different cell types can be found in one organ and, more important, a high number of blood cells in the organ may also influence the result. On the other hand, these results may indicate that PERVs were still actively replicating and integrating as new proviruses. In Banna minipigs, differences between 1.9 copies in the lung and 6.3 in the thyroid gland using primers specific for the gag gene sequence were reported [20]. This suggests that the lowest number 1.9 indicates the number of the original gag endogenous sequences and that in the thyroid gland the number of gag sequences increased three times. However, the published number 0 for PERV-A env sequences in the pancreas in contrast to 11.2 in the thyroid gland cannot be explained without studying the copy number in the germ line (oocytes, sperm). New investigations using highly purified DNA, sensitive detection methods, excellent standard curves and internal standards are required to study the copy number in different organs of a single pig. Droplet digital ${ }^{\mathrm{TM}} \mathrm{PCR}\left(\mathrm{ddPCR}^{\mathrm{TM}}\right)$ and higher coverage sequencing will be the methods of choice in order to determine the exact copy number of PERV proviruses, however the final determination will be hampered by the identity of multiple sequences of the proviruses.

Regardless of these results, expression of PERV at the RNA and protein level was found to differ significantly from organ to organ (Table 2) [29-33]. Reverse transcriptase PCR (RT-PCR) based methods measuring expression at the mRNA level as well as immunohistochemistry detecting PERV at the protein level have been used to study virus expression. The highest expression was found in the lung, and in the spleen. It is interesting to note that stimulation of pig PBMCs by a mitogen such as the $\mathrm{T}$ cell mitogen phytohemagglutinin (PHA) significantly increased virus gene expression. At a certain level of mRNA expression, release of virus particles may be expected [30,34-36]. Since the mitogen stimulation simulates an antigenic stimulus of the immune cells, it may also be expected that PERV expression increases when the immune system is stimulated for example due to a bacterial or viral infection. This may explain why the expression in the spleen, being an immune organ, is so high in most cases (Table 2). Based on the reported differences in the copy number $[20,28,29]$, the differences in the expression may be due not only to different transcription levels, but also to the different copy number of proviruses in the organs. However, when the number of proviruses was identical in all organs, significant differences in the level of expression of PERV in different organs were also observed [19]. 
Table 2. PERV expression in different tissues of different pig breeds.

\begin{tabular}{|c|c|c|c|c|c|c|c|c|c|c|c|c|c|}
\hline Animals & Remarks & Heart & Liver & Spleen & Brain & Lung & Muscle & Kidney & Pancreas & Lymph Node & Small Intestine & Skin & Reference \\
\hline $\begin{array}{c}\text { Hybrid } \\
\text { Landrace/Jeju }\end{array}$ & $\begin{array}{c}\text { Korea } \\
\text { pol primers }\end{array}$ & + & + & + & - & + & - & +++ & nt & nt & $\mathrm{nt}$ & $\mathrm{nt}$ & Yoon et al., [19] \\
\hline German landrace $^{a}$ & $\begin{array}{c}\text { Multitransgenic }{ }^{\mathrm{b}} \\
\text { gag primers }\end{array}$ & + & + & + & + & +++ & - & - & - & nt & nt & nt & Dieckhoff et al., [30 \\
\hline German landrace & $\begin{array}{l}\text { Non-transgenic } \\
\text { gag primers }\end{array}$ & - & + & +++ & nt & ++ & - & - & - & nt & nt & nt & Dieckhoff et al., [30 \\
\hline MMS Troll $^{\mathrm{c}}$ & gag primers & $\mathrm{nt}$ & $\mathrm{nt}$ & +++ & $\mathrm{nt}$ & $\mathrm{nt}$ & $\mathrm{nt}$ & nt & $\mathrm{nt}$ & $\mathrm{nt}$ & $\mathrm{nt}$ & - & Dieckhoff et al., [31 \\
\hline German landrace & $\begin{array}{l}\text { Non-transgenic } \\
\text { env PERV-A primers }\end{array}$ & + & + & +++ & - & + & + & ++ & nt & ++ & ++ & nt & Mazurek et al., [29] \\
\hline Yucatan micropig & $\begin{array}{l}\text { gag, pol primer } \\
\text { PERV-A }\end{array}$ & - & + & ++ & nt & +++ & nt & - & - & ++ & ++ & nt & Bittmann et al., [32 \\
\hline Yucatan micropig & PERV-C env primer & $\mathrm{nt}$ & - & + & $\mathrm{nt}$ & +++ & $\mathrm{nt}$ & $\mathrm{nt}$ & $\mathrm{nt}$ & + & $\mathrm{nt}$ & - & Bittmann et al., [32] \\
\hline Yucatan micropig & $\begin{array}{l}\text { Immunohistochemistry } \\
\text { Gag and p15E } \\
\text { proteins }\end{array}$ & ++ & - & +++ & ++ & nt & - & - & - & - & ++ & nt & Bittmann et al., [32 \\
\hline German landrace & pol primers & + & ++ & +++ & + & + & + & ++ & $\mathrm{nt}$ & ++ & nt & $\mathrm{nt}$ & Semaan et al., [33] \\
\hline
\end{tabular}




\section{PERV Activity and Cellular Restriction Factors}

Two main reasons may be discussed to explain the fact that HERVs are inactive in humans and that PERVs are highly active in pigs. First, pigs were infected with the PERV precursor only 7.5 million year ago, whereas the HERV precursors entered the human ancestral primate species around 28 million years. Second, during evolution, primates including humans have developed new and more powerful restriction mechanisms with the goal of inactivating the endogenous viruses more efficiently. APOBEC3 (apolipoprotein B mRNA-editing catalytic polypeptides, A3) proteins belong to these restriction factors; they deaminate DNA cytosines and block the replication of retroviruses and retrotransposons. Each $A 3$ gene encodes a protein with one or two conserved zinc-coordinating $\mathrm{Z}$ motifs. In pigs and in mice, also known to release infectious endogenous retroviruses, there are one $\mathrm{A} 3$ protein and two $\mathrm{Z}$ motifs, whereas in humans seven proteins and $11 \mathrm{Z}$ motifs were found, indicating that during evolution the protective potency of the host increased [37].

The mechanism on how retroviruses counteract or escape the A3s from their own host species is not well studied [38]. In the case of human immunodeficiency virus type 1 (HIV-1), the amount of A3G in cells infected with wild-type HIV-1 is dramatically reduced by a Vif-dependent degradation process via the ubiquitination-proteasome pathway [39-41]. However, little is known about A3-neutralising strategies used by retroviruses that do not encode a Vif protein or the foamy virus (FV) protein Bet $[42,43]$, both inhibiting the incorporation of A3 proteins into the virions. The mechanism of resistance of MuLVs to murine A3 (muA3) is still unclear [44-48]. However, recent data showed that muA3 is an important in vivo restriction factor of the Friend virus complex and the MoloneyMuLV [49-51]. Initial studies showed that porcine (po) A3Z2-Z3 strongly inhibits HIV-1 and weakly restricts MuLV [52].

Furthermore, it was reported that overexpressed poA3Z2-Z3 did not significantly interfere with PERV transmission, and it was concluded that PERV was resistant to its species-specific A3 protein [53]. Subsequently, the chromosomal porcine A3 locus for poA3Z2 and poA3Z3 was re-analysed [54,55]. The two A3 genes in pigs encode at least four different mRNAs: A3Z2, A3Z3, A3Z2-Z3, and A3Z2-Z3 splice variant A (SVA). It was found that PERV was significantly inhibited by various porcine A3s in single-round as well as in spreading virus assays. PERV inhibition strongly correlated with a specific cytidine deamination in viral genomes in the trinucleotide 5'TGC for poA3Z2 as well as poA3Z2-Z3 and 5'CAC for A3Z3 [54-56]. These results strongly suggest that human and porcine A3s could inhibit PERV replication in vivo, thereby reducing the risk of potential infection of human cells by PERV in the course of pig-to-human xenotransplantation.

In addition to APOBEC other restriction factors were described: the $\alpha$ isoform of tripartite motif-containing protein 5 (TRIM5 $\alpha$ ), which disrupts the viral capsid (CA) after cell entry, tripartite Motif-Containing Protein 28 (TRIM28), which blocks viral transcription, zinc-finger antiviral protein (ZAP), which directs degradation of viral RNAs, and tetherin, which traps virions on the surface of infected cells [57-60]. PERV-A and PERV-A/C are insensitive to restriction by TRIM5 $\alpha$ molecules in permissive feline Crandall-Reese feline kidney (CRFK) cells expressing TRIM5 $\alpha$ proteins from human, African green monkey, rhesus macaque, squirrel monkey, rabbit or cattle [61]. However, overexpression of either human or porcine tetherin in pig cells significantly reduced PERV production [62].

When the capacity of human APOBEC3G (hA3G) and tetherin to prevent PERV infection was compared, hA3G was a stronger inhibitor and a combination of both was the most effective way to restrict PERV [63].

\section{Evidence for Recombination and de Novo Integration in Vivo}

The most convincing evidence for a replication activity of PERVs in vivo is the finding of recombinations between the human tropic PERV-A and the ecotropic PERV-C in pigs. These recombinant PERV-A/C are not integrated in the germ line, but can be found in the cellular DNA from some organs (for review see [27]). They are characterised by a higher replication rate [64,65]. 
Despite this, first attempts to infect pigs with a PERV-A/C recombinant failed, certainly due to the innate immune system [66].

Recombinations between two defective proviruses may eventually result in a replication competent virus. Such a resurrection of endogenous retroviruses has been observed in antibody-deficient mice [67]. In $R a g 1^{-/-}$mice a recombination between the endogenous replication deficient sequence $E m v 2$ and non-ecotropic virus sequences resulted in viruses able to infect mice. Several recombination events were required to restore Emv2 infectivity, the resurrected virus infected the germ line and was transmitted as an endogenous retrovirus to progeny. Furthermore, the virus was able to induce tumours. It was shown that the lack of antibodies obviously allowed microbial translocation and stimulation of immune cells by lipopolysaccharides and other bacteria derived mitogens, increasing the expression of endogenous virus sequences and recombination in the stimulated cells. A similar mechanism may be possible in the case of PERV when immune cells were stimulated by microorganisms leading to an enhanced PERV expression and recombination.

Since John Coffin and coworkers found recently unfixed HERV-K sequences in some individuals with intact reading frames and expressed as functional proteins [68], the question arose whether HERVs may recombine with PERVs. Packaging of HERV sequences was undetectable in PERV particles produced from human cells expressing different HERVs [69], indicating that the potential for recombination of PERV and HERV sequences is low and that novel viruses generated by this mechanism are unlikely to represent a risk for xenotransplantation.

\section{Implications for Pig Testing for Xenotransplantation}

To perform a safe xenotransplantation and to prevent PERV transmission to the human recipient, PERV-C free animals with low expression of PERV-A and PERV-B should be selected as donors. To screen animals, easily available source materials such as blood, saliva, ear biopsies, or faeces may be used. If, however, the copy number in the organ needed for transplantation is different when compared with the available source material, additional investigation of the whole animal, or of sisters or brothers have to be performed.

\section{Inactivation of PERVs by Gene Editing}

First attempts to eliminate the multiple proviruses by gene editing were performed by zinc finger nucleases (ZFN) specific for highly conserved sequences in the pol region, however cytotoxic effects were observed, possibly due to the high copy number of the proviruses [70]. Recently the inactivation of 62 PERVs in the immortal pig cell line PK-15 by the clustered regularly interspaced short palindromic repeats/CRISPR-associated nuclease (CRISPR/Cas) technology was shown [26], suggesting that the PERV problem may be solved this way. However, it is still unclear whether it will be possible to inactivate all or at least the replication-competent PERVs in the genome and to generate healthy piglets by this strategy [71]. To generate PERV free pigs, primary cells have to be treated with PERV-specific CRISPR/Cas and these treated primary cells should be used for nuclear transfer. Since the number of cell divisions of primary cells is limited (Hayflick limit), cloning and selection of cells with PERVs inactivated by CRISPR/Cas may be difficult.

Interestingly, when HIV-1 infected cells have been treated with a HIV-1 specific CRISPR/Cas, insertions and deletions (indels) were observed impairing the function of the provirus [72,73]. Unexpectedly, some indels led to the emergence of replication competent HIV-1 resistant to CRISPR/Cas. These indels were the result of changing the target DNA sequence. Since PERV is replicating under certain circumstances in some cells of the pig, such a resistance against CRISPR/Cas, although very unlikely, may not be excluded. A combinatorial strategy using CRISPR/Cas targeting different sequences in PERV may prevent this [73]. Infection of the germ line with these viruses and transmission to the progeny is highly unlikely. 


\section{Conclusions}

There is clear evidence that PERVs replicate in vivo in the pig, and that this activity results in newly integrated proviruses which were absent from the germ line. This has to be considered when animals with a low copy number and low expression of PERV are selected for xenotransplantation. Improved methods to measure the copy number and the expression level will be required when pre-selecting animals for inactivation of PERVs using the CRISPR/Cas technology and demonstrating the absence of expression.

Acknowledgments: I would like to thank V. A. Morozov for fruitful discussions and critical reading of the text.

Conflicts of Interest: The author declares no conflict of interest.

\section{References}

1. Mager, D.L.; Stoye, J.P. Mammalian Endogenous Retroviruses. Microbiol. Spectr. 2015, 3. [CrossRef] [PubMed]

2. Dewannieux, M.; Heidmann, T. Endogenous retroviruses: Acquisition, amplification and taming of genome invaders. Curr. Opin. Virol. 2013, 3, 646-656. [CrossRef] [PubMed]

3. Denner, J. Endogenous retroviruses. In Retroviruses: Molecular Biology, Genomics and Pathogenesis; Kurth, R., Bannert, N., Eds.; Caister Academic Press: Hethersett, UK, 2010; pp. 35-69.

4. Bannert, N.; Kurth, R. The evolutionary dynamics of human endogenous retroviral families. Annu. Rev. Genomics Hum. Genet. 2006, 7, 149-173. [CrossRef] [PubMed]

5. Denner, J. Expression and function of endogenous retroviruses in the placenta. APMIS 2016, 124, 31-43. [CrossRef] [PubMed]

6. Morozov, V.A.; Dao Thi, V.L.; Denner, J. The transmembrane protein of the human endogenous retrovirus-K (HERV-K) modulates cytokine release and gene expression. PLoS ONE 2013, 8, e70399. [CrossRef] [PubMed]

7. Chuong, E.B.; Elde, N.C.; Feschotte, C. Regulatory evolution of innate immunity through co-option of endogenous retroviruses. Science 2016, 351, 1083-1087. [CrossRef] [PubMed]

8. Weiss, R.A. On the concept and elucidation of endogenous retroviruses. Philos. Trans. R. Soc. Lond. B. Biol. Sci. 2013, 368, 20120494. [CrossRef] [PubMed]

9. Denner, J.; Tönjes, R.R. Infection barriers to successful xenotransplantation focusing on porcine endogenous retroviruses. Clin. Microbiol. Rev. 2012, 25, 318-343. [CrossRef] [PubMed]

10. Wilson, C.A. Porcine endogenous retroviruses and xenotransplantation. Cell. Mol. Life Sci. 2008, 65, 3399-3412. [CrossRef] [PubMed]

11. Reus, K.; Mayer, J.; Sauter, M.; Zischler, H.; Müller-Lantzsch, N.; Meese, E. HERV-K(OLD): Ancestor sequences of the human endogenous retrovirus family HERV-K(HML-2). J. Virol. 2001, 75, 8917-8926. [CrossRef] [PubMed]

12. Tönjes, R.R.; Niebert, M. Relative age of proviral porcine endogenous retrovirus sequences in Sus scrofa based on the molecular clock hypothesis. J. Virol. 2003, 77, 12363-12368. [CrossRef] [PubMed]

13. Niebert, M.; Tönjes, R.R. Evolutionary spread and recombination of porcine endogenous retroviruses in the suiformes. J. Virol. 2005, 79, 649-654. [CrossRef] [PubMed]

14. Le Tissier, P.; Stoye, J.P.; Takeuchi, Y.; Patience, C.; Weiss, R.A. Two sets of human-tropic pig retrovirus. Nature 1997, 389, 681-682. [CrossRef] [PubMed]

15. Patience, C.; Takeuchi, Y.; Weiss, R.A. Infection of human cells by an endogenous retrovirus of pigs. Nat. Med. 1997, 3, 282-286. [CrossRef] [PubMed]

16. Patience, C.; Switzer, W.M.; Takeuchi, Y.; Griffiths, D.J.; Goward, M.E.; Heneine, W.; Stoye, J.P.; Weiss, R.A. Multiple groups of novel retroviral genomes in pigs and related species. J. Virol. 2001, 75, 2771-2775. [CrossRef] [PubMed]

17. Liu, G.; Li, Z.; Pan, M.; Ge, M.; Wang, Y.; Gao, Y. Genetic prevalence of porcine endogenous retrovirus in Chinese experimental miniature pigs. Transplant. Proc. 2011, 43, 2762-2769. [CrossRef] [PubMed]

18. Lee, D.; Lee, J.; Yoon, J.K.; Kim, N.Y.; Kim, G.W.; Park, C.; Oh, Y.K.; Kim, Y.B. Rapid determination of perv copy number from porcine genomic DNA by real-time polymerase chain reaction. Anim. Biotechnol. 2011, 22, 175-180. [CrossRef] [PubMed] 
19. Yoon, J.K.; Choi, J.; Lee, H.J.; Cho, Y.; Gwon, Y.D.; Jang, Y.; Kim, S.; Choi, H.; Lee, J.H.; Kim, Y.B. Distribution of Porcine Endogenous Retrovirus in Different Organs of the Hybrid of a Landrace and a Jeju Domestic Pig in Korea. Transplant. Proc. 2015, 47, 2067-2071. [CrossRef] [PubMed]

20. Zhang, P.; Yu, P.; Wang, W.; Zhang, L.; Li, S.; Bu, H. An effective method for the quantitative detection of porcine endogenous retrovirus in pig tissues. In Vitro Cell Dev. Biol. Anim. 2010, 46, 408-410. [CrossRef] [PubMed]

21. Quereda, J.J.; Herrero-Medrano, J.M.; Abellaneda, J.M.; García-Nicolás, O.; Martínez-Alarcón, L.; Pallarés, F.J.; Ramírez, P.; Muñoz, A.; Ramis, G. Porcine endogenous retrovirus copy number in different pig breeds is not related to genetic diversity. Zoonoses Public Health 2012, 59, 401-407. [CrossRef] [PubMed]

22. Mang, R.; Maas, J.; Chen, X.; Goudsmit, J.; van der Kuyl, A.C. Identification of a novel type C porcine endogenous retrovirus: Evidence that copy number of endogenous retroviruses increases during host inbreeding. J. Gen. Virol. 2001, 82, 1829-1834. [CrossRef] [PubMed]

23. Lee, J.H.; Webb, G.C.; Allen, R.D.; Moran, C. Characterizing and mapping porcine endogenous retroviruses in Westran pigs. J. Virol. 2002, 76, 5548-5556. [CrossRef] [PubMed]

24. Garkavenko, O.; Wynyard, S.; Nathu, D.; Muzina, M.; Muzina, Z.; Scobie, L.; Hector, R.D.; Croxson, M.C.; Tan, P.; Elliott, B.R. Porcine endogenous retrovirus transmission characteristics from a designated pathogen-free herd. Transplant. Proc. 2008, 40, 590-593. [CrossRef] [PubMed]

25. Groenen, M.A.; Archibald, A.L.; Uenishi, H.; Tuggle, C.K.; Takeuchi, Y.; Rothschild, M.F.; Rogel-Gaillard, C.; Park, C.; Milan, D.; Megens, H.-J.; et al. Analyses of pig genomes provide insight into porcine demography and evolution. Nature 2012, 491, 393-398. [CrossRef] [PubMed]

26. Yang, L.; Güell, M.; Niu, D.; George, H.; Lesha, E.; Grishin, D.; Aach, J.; Shrock, E.; Xu, W.; Poci, J.; et al. Genome-wide inactivation of porcine endogenous retroviruses (PERVs). Science 2015, 350, 1101-1104. [CrossRef] [PubMed]

27. Denner, J. Recombinant porcine endogenous retroviruses (PERV-A/C): A new risk for xenotransplantation? Arch. Virol. 2008, 153, 1421-1426. [CrossRef] [PubMed]

28. Sypniewski, D.; Machnik, G.; Mazurek, U.; Wilczok, T.; Smorag, Z.; Jura, J.; Gajda, B. Distribution of porcine endogenous retroviruses (PERVs) DNA in organs of a domestic pig. Ann. Transplant. 2005, 10, 46-51. [PubMed]

29. Mazurek, U.; Kimsa, M.C.; Strzalka-Mrozik, B.; Kimsa, M.W.; Adamska, J.; Lipinski, D.; Zeyland, J.; Szalata, M.; Slomski, R.; Jura, J.; et al. Quantitative analysis of porcine endogenous retroviruses in different organs of transgenic pigs generated for xenotransplantation. Curr. Microbiol. 2013, 67, 505-514. [CrossRef] [PubMed]

30. Dieckhoff, B.; Kessler, B.; Jobst, D.; Kues, W.; Petersen, B.; Pfeifer, A.; Kurth, R.; Niemann, H.; Wolf, E.; Denner, J. Distribution and expression of porcine endogenous retroviruses in multi-transgenic pigs generated for xenotransplantation. Xenotransplantation 2009, 16, 64-73. [CrossRef] [PubMed]

31. Dieckhoff, B.; Puhlmann, J.; Büscher, K.; Hafner-Marx, A.; Herbach, N.; Bannert, N.; Büttner, M.; Wanke, R.; Kurth, R.; Denner, J. Expression of porcine endogenous retroviruses (PERVs) in melanomas of Munich miniature swine (MMS) Troll. Vet. Microbiol. 2007, 123, 53-68. [CrossRef] [PubMed]

32. Bittmann, I.; Mihica, D.; Plesker, R.; Denner, J. Expression of porcine endogenous retroviruses (PERV) in different organs of a pig. Virology 2012, 433, 329-336. [CrossRef] [PubMed]

33. Semaan, M.; Kaulitz, D.; Petersen, B.; Niemann, H.; Denner, J. Long-term effects of PERV-specific RNA interference in transgenic pigs. Xenotransplantation 2012, 19, 112-121. [CrossRef] [PubMed]

34. Wilson, C.A.; Wong, S.; Muller, J.; Davidson, C.E.; Rose, T.M.; Burd, P. Type C retrovirus released from porcine primary peripheral blood mononuclear cells infects human cells. J. Virol. 1998, 72, 3082-3087. [PubMed]

35. Tacke, S.J.; Specke, V.; Denner, J. Differences in release and determination of subtype of porcine endogenous retroviruses produced by stimulated normal pig blood cells. Intervirology 2003, 46, 17-24. [CrossRef] [PubMed]

36. Semaan, M.; Rotem, A.; Barkai, U.; Bornstein, S.; Denner, J. Screening pigs for xenotransplantation: Prevalence and expression of porcine endogenous retroviruses in Göttingen minipigs. Xenotransplantation 2013, 20, 148-156. [CrossRef] [PubMed]

37. LaRue, R.S.; Jónsson, S.R.; Silverstein, K.A.T.; Lajoie, M.; Bertrand, D.; El-Mabrouk, N.; Hötzel, I.; Andrésdóttir, V.; Smith, T.P.; Harris, R.S. The artiodactyl APOBEC3 innate immune repertoire shows evidence for a multi-functional domain organization that existed in the ancestor of placental mammals. BMC Mol. Biol. 2008, 9, 104. [CrossRef] [PubMed] 
38. Ross, S.R. Are viruses inhibited by APOBEC3 molecules from their host species? PLoS Pathog. 2009, 5, e1000347. [CrossRef] [PubMed]

39. Marin, M.; Rose, K.M.; Kozak, S.L.; Kabat, D. HIV-1 Vif protein binds the editing enzyme APOBEC3G and induces its degradation. Nat. Med. 2003, 9, 1398-1403. [CrossRef] [PubMed]

40. Sheehy, A.M.; Gaddis, N.C.; Malim, M.H. The antiretroviral enzyme APOBEC3G is degraded by the proteasome in response to HIV-1 Vif. Nat. Med. 2003, 9, 1404-1407. [CrossRef] [PubMed]

41. Yu, Y.; Xiao, Z.; Ehrlich, E.S.; Yu, X.; Yu, X.F. Selective assembly of HIV-1 Vif-Cul5-ElonginB-ElonginC E3 ubiquitin ligase complex through a novel SOCS box and upstream cysteines. Genes Dev. 2004, 18, $2867-2872$. [CrossRef] [PubMed]

42. Löchelt, M.; Romen, F.; Bastone, P.; Muckenfuss, H.; Kirchner, N.; Kim, Y.B.; Truyen, U.; Rösler, U.; Battenberg, M.; Saib, A.; et al. The antiretroviral activity of APOBEC3 is inhibited by the foamy virus accessory Bet protein. Proc. Natl. Acad. Sci. USA 2005, 102, 7982-7987. [CrossRef] [PubMed]

43. Russell, R.A.; Wiegand, H.L.; Moore, M.D.; Schäfer, A.; McClure, M.O.; Cullen, B.R. Foamy virus Bet proteins function as novel inhibitors of the APOBEC3 family of innate antiretroviral defense factors. J. Virol. 2005, 79, 8724-8731. [CrossRef] [PubMed]

44. Bishop, K.N.; Holmes, R.K.; Sheehy, A.M.; Davidson, N.O.; Cho, S.J. Cytidine deamination of retroviral DNA by diverse APOBEC proteins. Curr. Biol. 2004, 14, 1392-1396. [CrossRef] [PubMed]

45. Browne, E.P.; Littman, D.R. Species-specific restriction of apobec3-mediated hypermutation. J. Virol. 2008, 82, 1305-1313. [CrossRef] [PubMed]

46. Jern, P.; Stoye, J.P.; Coffin, J.M. Role of APOBEC3 in genetic diversity among endogenous murine leukemia viruses. PLoS. Genet. 2007, 3, 2014-2022. [CrossRef] [PubMed]

47. Kobayashi, M.; Takaori-Kondo, A.; Shindo, V.; Abudu, V.; Fukunaga, K. APOBEC3G targets specific virus species. J. Virol. 2004, 78, 8238-8244. [CrossRef] [PubMed]

48. Langlois, M.A.; Kemmerich, K.; Rada, C.; Neuberger, M.S. The AKV murine leukemia virus is restricted and hypermutated by mouse APOBEC3. J. Virol. 2009, 83, 11550-11559. [CrossRef] [PubMed]

49. Low, A.; Okeoma, C.M.; Lovsin, N.; de las Heras, M.; Taylor, T.H.; Peterlin, B.M.; Ross, S.R.; Fan, H. Enhanced replication and pathogenesis of Moloney murine leukemia virus in mice defective in the murine APOBEC3 gene. Virology 2009, 385, 455-463. [CrossRef] [PubMed]

50. Santiago, M.L.; Montano, M.; Benitez, R.; Messer, R.J.; Yonemoto, W. Apobec3 encodes Rfv3, a gene influencing neutralizing antibody control of retrovirus infection. Science 2008, 321, 1343-1346. [CrossRef] [PubMed]

51. Takeda, E.; Tsuji-Kawahara, S.; Sakamoto, M.; Langlois, M.A.; Neuberger, M.S. Mouse APOBEC3 restricts friend leukemia virus infection and pathogenesis in vivo. J. Virol. 2008, 82, 10998-11008. [CrossRef] [PubMed]

52. Jonsson, S.R.; Hache, G.; Stenglein, M.D.; Fahrenkrug, S.C.; Andresdottir, V. Evolutionarily conserved and non-conserved retrovirus restriction activities of artiodactyl APOBEC3F proteins. Nucleic Acids Res. 2006, 34, 5683-5694. [CrossRef] [PubMed]

53. Jonsson, S.R.; Larue, R.S.; Stenglein, M.D.; Fahrenkrug, S.C.; Andresdottir, V. The Restriction of Zoonotic PERV Transmission by Human APOBEC3G. PLoS ONE 2007, 2, e893. [CrossRef] [PubMed]

54. Dörrschuck, E.; Fischer, N.; Bravo, I.G.; Hanschmann, K.M.; Kuiper, H. Restriction of Porcine Endogenous Retrovirus by Porcine APOBEC3 Cytidine Deaminases. J Virol. 2011, 85, 3842-3857. [CrossRef] [PubMed]

55. Dörrschuck, E.; Münk, C.; Tönjes, R.R. APOBEC3 proteins and porcine endogenous retroviruses. Transplant. Proc. 2008, 40, 959-961. [CrossRef] [PubMed]

56. Lee, J.; Choi, J.Y.; Lee, H.J.; Kim, K.C.; Choi, B.S. Repression of porcine endogenous retrovirus infection by human APOBEC3 proteins. Biochem. Biophys. Res. Commun. 2011, 407, 266-270. [CrossRef] [PubMed]

57. Goff, S.P. HIV: Replication trimmed back. Nature 2004, 427, 791-793. [CrossRef] [PubMed]

58. Goff, S.P. Retrovirus restriction factors. Mol. Cell 2004, 16, 849-859. [CrossRef] [PubMed]

59. Meije, Y.; Tönjes, R.R.; Fishman, J.A. Retroviral Restriction Factors and Infectious Risk in Xenotransplantation. Am. J. Transplant. 2010, 10, 1511-1516. [CrossRef] [PubMed]

60. Wolf, D.; Goff, S.P. Host restriction factors blocking retroviral replication. Annu. Rev. Genet. 2008, 42, $143-163$. [CrossRef] [PubMed] 
61. Wood, A.; Webb, B.L.; Bartosch, B.; Schaller, T.; Takeuchi, Y.; Towers, G.J. Porcine endogenous retroviruses PERVA and $\mathrm{A} / \mathrm{C}$ recombinant are insensitive to a range of divergent mammalian TRIM5alpha proteins including human TRIM5alpha. J. Gen. Virol. 2009, 90, 702-709. [CrossRef] [PubMed]

62. Mattiuzzo, G.; Ivol, S.; Takeuchi, S. Regulation of porcine endogenous retrovirus release by porcine and human tetherins. J. Virol. 2010, 84, 2618-2622. [CrossRef] [PubMed]

63. Bae, E.H.; Jung, Y.T. Comparison of the effects of retroviral restriction factors involved in resistance to porcine endogenous retrovirus. J. Microbiol. Biotechnol. 2014, 24, 577-583. [CrossRef] [PubMed]

64. Harrison, I.; Takeuchi, Y.; Bartosch, B.; Stoye, J.P. Determinants of high titer in recombinant porcine endogenous retroviruses. J. Virol. 2004, 78, 13871-13879. [CrossRef] [PubMed]

65. Denner, J.; Specke, V.; Thiesen, U.; Karlas, A.; Kurth, R. Genetic alterations of the long terminal repeat of an ecotropic porcine endogenous retrovirus during passage in human cells. Virology 2003, 314, 125-133. [CrossRef]

66. Kaulitz, D.; Mihica, D.; Plesker, R.; Geissler, A.; Tönjes, R.R.; Denner, J. Absence of infection in pigs inoculated with high-titre recombinant PERV-A/C. Arch. Virol. 2011, 156, 707-710. [CrossRef] [PubMed]

67. Young, G.R.; Eksmond, U.; Salcedo, R.; Alexopoulou, L.; Stoye, J.P.; Kassiotis, G. Resurrection of endogenous retroviruses in antibody-deficient mice. Nature 2012, 491, 774-778. [CrossRef] [PubMed]

68. Wildschutte, J.H.; Williams, Z.H.; Montesion, M.; Subramanian, R.P.; Kidd, J.M.; Coffin, J.M. Discovery of unfixed endogenous retrovirus insertions in diverse human populations. Proc. Natl. Acad. Sci. USA 2016, 113, E2326-E2334. [CrossRef] [PubMed]

69. Suling, K.; Quinn, G.; Wood, J.; Patience, C. Packaging of human endogenous retrovirus sequences is undetectable in porcine endogenous retrovirus particles produced from human cells. Virology 2003, 312, 330-336. [CrossRef]

70. Semaan, M.; Ivanusic, D.; Denner, J. Cytotoxic Effects during Knock Out of Multiple Porcine Endogenous Retrovirus (PERV) Sequences in the Pig Genome by Zinc Finger Nucleases (ZFN). PLoS ONE 2015, 10, e0122059. [CrossRef] [PubMed]

71. Denner, J. Elimination of porcine endogenous retroviruses from pig cells. Xenotransplantation 2015, 22, 411-412. [CrossRef] [PubMed]

72. Wang, Z.; Pan, Q.; Gendron, P.; Zhu, W.; Guo, F.; Cen, S.; Wainberg, M.A.; Liang, C. CRISPR/Cas9-Derived Mutations both Inhibit HIV-1 Replication and Accelerate Viral Escape. Cell Rep. 2016, 15, 481-489. [CrossRef] [PubMed]

73. Liang, C.; Wainberg, M.A.; Das, A.T.; Berkhout, B. CRISPR/Cas9: A double-edged sword when used to combat HIV infection. Retrovirology 2016, 13, 37. [CrossRef] [PubMed] 